\title{
Dual antiplatelet therapy and drug eluting stents: a marriage of convenience
}

\author{
Juan Benezet-Mazuecos, Borja Ibanez and Juan J Badimon*
}

\author{
Address: Cardiovascular Biology Research Laboratory, Cardiovascular Institute, Mount Sinai School of Medicine, New York, NY, USA \\ Email: Juan Benezet-Mazuecos - jbenezet@yahoo.es; Borja Ibanez - borja.ibanez@mssm.edu; Juan J Badimon* - juan.badimon@mssm.edu \\ * Corresponding author
}

Published: I October 2007

Thrombosis Journal 2007, 5:15 doi:10.1186/1477-9560-5-15

This article is available from: http://www.thrombosisjournal.com/content/5/I/I5

(c) 2007 Benezet-Mazuecos et al; licensee BioMed Central Ltd.

This is an Open Access article distributed under the terms of the Creative Commons Attribution License (http://creativecommons.org/licenses/by/2.0), which permits unrestricted use, distribution, and reproduction in any medium, provided the original work is properly cited.

In 1977, a major breakthrough in cardiovascular medicine was introduced by Dr. Andreas Gruentzig. In September of that year, Gruentzig performed the very first percutaneous transluminal coronary angioplasty (PTCA) procedure in a human. Twenty-three years later, the coronary artery was still patent. [1] Despite the initial enthusiasm, some complications were clearly associated with the procedure, being restenosis and thrombosis the major problems to deal with. In the early nineties, bare metal stents (BMS) were introduced to avoid the so called "elastic recoil of the artery" leading to restenosis. Despite some improvements in the rates of restenosis and thrombosis, they were still very significant. The introduction of dual antiplatelet therapy (thyenopiridine on top of aspirin) substantially decreased the rate of stent thrombosis, being currently a rare complication occurring in less than $1 \%$ of the procedures. [2]

Despite the "elastic recoil" of the artery was abrogated with the stent deployment, there was still a non-depreciable rate of in-stent restenosis due to the neointimal proliferation inside the stents. In an attempt to fight the exaggerated proliferation after coronary stent implantation, our lab first used rapamycin in an animal model of restenosis showing the effectiveness of this antiproliferative drug in preventing this neointimal proliferation. [3] Soon after, stents locally delivering antiproliferative drugs (the so called drug eluting stents [DES]) were designed and tested in humans with impressive results in terms of in-stent restenosis inhibition. Two drug-eluting stents (DES), the Cypher stent (Cordis/Johnson \& Johnson) and Taxus stent (Boston Scientific), were introduced. The Cypher and Taxus stents are produced by coating a stain-
Received: II September 2007

Accepted: I October 2007 less-steel stent with a thin layer of a non-erodable synthetic polymer containing either sirolimus or paclitaxel respectively. DES implantation resulted in a rate of restenosis below 10\% (compared to 30\% observed after bare metal stents implantation) [4-6], with a similar rate of instent thrombosis. $[7,8]$ It is important to remind that dual antiplatelet therapy was mandatory for at least 3-6 months after DES implantation. However some initial warns were raised by few groups suggesting that DES do not undergo a complete re-endothelization. $[9,10]$ It was just a matter of time to face, with striking surprise, the unexpected high rate of late ( $>30$ days after stent deployment) and especially very late in-stent thrombosis (beyond 12 months from stent implantation) in DES compared to bare metal stents. [11,12] Further cause for concern came from the Basel Stent Cost-effectiveness Trial-Late Thrombotic Events (BASKET-LATE) data, which showed that among 746 DES or BMS patients who had dual antiplatelet therapy discontinued after the first six months, the rate of cardiac death or non-fatal MI over the following year was higher in patients with DES than BMS ( $4.9 \%$ versus $1.3 \%$; $\mathrm{p}=0.01$ ), and that this was likely to be related to late stent thrombosis, which presented as death or MI in $88 \%$ of cases. [13] After this first report, a heated discussion began over the safety of DES, especially when the protective umbrella of dual antiplatelet therapy is discontinued. Dr. Camenzind presented in the WCC2006 in Spain a meta-analysis of first generation DES in comparison to BMS accounting for a total of $n=878$ sirolimus eluting stent (SES) vs $\mathrm{n}=870 \mathrm{BMS}$ (RAVEL, SIRIUS, C-SIRIUS and E-SIRIUS) and $\mathrm{n}=1685$ paclitaxeleluting stents (PES) vs $\mathrm{n}=1675$ BMS (TAXUS II, IV-VI). The incidence - up to the latest available follow-up - of 
total mortality and Q-wave MI combined were 38\% (SES) and $16 \%$ (PES) higher in DES as compared to control BMS (p-value: SES vs BMS: 0.03 ; PES vs BMS. 0.68). [14] Overall, it seems that experience has shown that the success of DES comes at a price: patients using DES could be trading restenosis, which is seldom life-threatening, for in-stent thrombosis, which may lead to death and myocardial infarction. Moreover, a number of reports imply that thrombosis rates of DES may even be higher in the "real world" than in clinical trials where stents are used "on-label". Today it is considered that as much as $60 \%$ of coronary percutaneous procedures are "off-label". When DES are used "off-label", it is estimated that the rates of thrombosis are higher. On the other hand, although data from large registries and meta-analyses of randomized trials indicate a higher risk for DES thrombosis, others recent studies claim the absence of such increased risk. [15] The controversy is open.

Three are the major players involved in the pathological processes leading to late in-stent thrombosis: the stent coated with an antiproliferative drug, the vulnerability (thrombogenicity) of the patient's blood, and the antiplatelet therapy.

Several factors related with the stents are associated with an increased risk of thrombosis, including the procedure itself (stent malapposition and/or underexpansion, number of implanted stents, length, persistent slow coronary blood flow, and dissections) and stent design (materials, strut thickness and polymer type). The coating of stents with antiproliferative (sirolimus) and/or cytostatic (paclitaxel) drugs should have the additional advantage of inhibiting the proliferation of vascular cells. [10]

Reendothelialization occurs after vascular injury and similarly after stent placement. But then two questions arise since damaged and/or dysfunctional endothelium is directly related with the development and progression of atherosclerosis $[16,17]$ : Could the DES selectively inhibit the proliferation and migration of smooth muscle cells without affecting the growth of the endothelial cells? And could it be possible for DES to exert their antirestenotic effects without affecting the neo-endothelialization of the struts? In vitro, rapamycin and paclitaxel not only inhibit proliferation and migration of vascular smooth muscle cells but equally suppress endothelial cells, thereby potentially impairing reendothelialization. A post-mortem study comparing coronary segments from patients after DES and BMS implantation revealed delayed arterial healing and poorer endothelialization after DES compared with BMS implantation of similar duration. [10] Thus, current evidence suggests delayed reendothelialization and arterial healing after implantation of DES compared with BMS, resulting in potentially enhanced thrombo- genicity. Many factors influence the healing process and vary with individual risk factors. Coating of stents with substances that potentially facilitate reendothelialization may represent a novel therapeutic approach. Significant advances in material engineering are poised to produce biodegradable stents. [18]

Several risk factors correlate with "vulnerable/hyperreactive blood" (diabetes, smoking, hyperlipidemia, inflammatory states, cathecholamines...). Also, several patientrelated factors have been associated with the development of in-stent thrombosis, including low ejection fraction, diabetes mellitus, advanced age, renal failure, and acute coronary syndromes. In particular, in this last situation it could be due to delayed healing, lack of endothelialization, and presence of a pronounced inflammatory and thrombogenic environment combined by enhanced platelet reactivity. Furthermore, certain lesion characteristics (bifurcation complex or in-stent restenosis lesions) are reported to be associated with an increased risk of stent thrombosis. [11,19]

The majority of the retrospective studies on the rate of late in-stent thrombosis have identified the window of 6 to 9 months post stenting as the peak of more incidence. The majority of the studies using multivariate analysis have identified the discontinuation of dual antithrombotic therapy as the principal parameter responsible for stent thrombosis. $[20,21]$ Stents are foreign bodies in the vessel wall and thus induce platelet adhesion and activation of the coagulation cascade. Furthermore, high-pressure implantation induces significant vascular injury, with exposure of thrombogenic molecules of the subintima and media (including plaque material) to the blood stream. As a consequence, only potent platelet inhibition made the procedure feasible. [22] The association between late thrombosis with delayed stent coverage and cessation of dual antithrombotic therapy strongly suggest the need for a longer period of combination therapy. On the other hand, longer administration of dual therapy is hampered by its higher cost, patient compliance and the possibility of increased bleeding complications. The appropriate duration of the long-term antiplatelet regimen for prevention of DES thrombosis remains to be assessed in randomized prospective trials; at present, a course of 12 months of dual-antiplatelet therapy may be considered. [23]

Therefore, in an example of individualized medicine, many factors should be taken into account for the selection of the type of stent to be implanted. Among these factors, the patient characteristics (diabetes, left ventricular ejection fraction ...), the severity of the disease and the characteristics of the lesions, and finally the possibility and/or compliance to a prolonged antithrombotic treat- 
ment. What seem to be clear is that a longer period of dual anti-platelet therapy is needed for patients undergoing DES implantation than for those receiving a bare metal stent. However, at this point it is completely unknown how longer that period should be. Despite the current recommendations from the AHA/ACC suggest 12 months of dual antiplatelet therapy, some experts highly suggest a chronic dual antiplatelet therapy until new data with longer follow up periods is available.

\section{References}

I. King SB 3rd, Meier B: Interventional treatment of coronary heart disease and peripheral vascular disease. Circulation 2000, 102:IV8I-86

2. Bertrand ME, Rupprecht HJ, Urban P, Gershlick AH: Double-blind study of the safety of clopidogrel with and without a loading dose in combination with aspirin compared with ticlopidine in combination with aspirin after coronary stenting: the clopidogrel aspirin stent international cooperative study (CLASSICS). Circulation 2000, 102:624-629.

3. Gallo R, Padurean A, Jayaraman T, Marx S, Roque M, Adelman S, Chesebro J, Fallon J, Fuster V, Marks A, Badimon JJ: Inhibition of intimal thickening after balloon angioplasty in porcine coronary arteries by targeting regulators of the cell cycle. Circulation 1999, 99:2164-2170.

4. Smith SC, Dove JT, Jacobs AK, Kennedy JW, Kereiakes D, Kern MJ, Kuntz RE, Popma J], Schaff HV, Williams DO, Gibbons RJ, Alpert JP, Eagle KA, Faxon DP, Fuster V, Gardner TJ, Gregoratos G, Russell RO, Smith SC: ACC/AHA guidelines of percutaneous coronary interventions (revision of the 1993 PTCA guidelines) - executive summary. A report of the American College of Cardiology/American Heart Association Task Force on Practice Guidelines (committee to revise the 1993 guidelines for percutaneous transluminal coronary angioplasty). J Am Coll Cardiol 200I, 37:2215-2239.

5. Morice MC, Serruys PW, Sousa JE, Fajadet J, Ban Hayashi E, Perin M, Colombo A, Schuler G, Barragan P, Guagliumi G, Molnar F, Falotico $\mathrm{R}$ : A randomized comparison of a sirolimus-eluting stent with a standard stent for coronary revascularization. $N$ EnglJ Med 2002, 346: $1773-1780$.

6. Moses JW, Leon MB, Popma JJ, Fitzgerald PJ, Holmes DR, O'Shaughnessy C, Caputo RP, Kereiakes DJ, Williams DO, Teirstein PS, Jaeger $\mathrm{JL}$, Kuntz RE: Sirolimus-eluting stents versus standard stents in patients with stenosis in a native coronary artery. N EnglJ Med 2003, 349:1315-1323.

7. Moreno R, Fernandez C, Hernandez R, Alfonso F, Angiolillo DJ, Sabate M, Escaned J, Banuelos C, Fernandez-Ortiz A, Macaya C: Drug-eluting stent thrombosis: results from a pooled analysis including 10 randomized studies. I Am Coll Cardiol 2005, 45:954-959.

8. Babapulle MN, Joseph L, Belisle P, Brophy JM, Eisenberg MJ: A hierarchical Bayesian meta-analysis of randomised clinical trials of drug-eluting stents. Lancet 2004, 364:583-591.

9. Takano M, Ohba T, Inami S, Seimiya K, Sakai S, Mizuno K: Angioscopic differences in neointimal coverage and in persistence of thrombus between sirolimus-eluting stents and bare metal stents after a 6-month implantation. Eur Heart J 2006, 27:2189-2195

10. Joner M, Finn AV, Farb A, Mont EK, Kolodgie FD, Ladich E, Kutys R, Skorija K, Gold HK, Virmani R: Pathology of drug-eluting stents in humans: delayed healing and late thrombotic risk. J Am Coll Cardiol 2006, 48: 193-202.

II. lakovou I, Schmidt T, Bonizzoni E, Ge L, Sangiorgi GM, Stankovic G, Airoldi F, Chieffo A, Montorfano M, Carlino M, Michev I, Corvaja N, Briguori C, Gerckens U, Grube E, Colombo A: Incidence, predictors, and outcome of thrombosis after successful implantation of drug-eluting stents. JAMA 2005, 293:2। 26-2। 30.

12. Ong AT, McFadden EP, Regar E, de Jaegere PP, van Domburg RT, Serruys PW: Late angiographic stent thrombosis (LAST) events with drug-eluting stents. J Am Coll Cardiol 2005, 45:2088-2092.

13. Pfisterer M, Brunner-La Rocca HP, Buser PT, Rickenbacher P, Hunziker P, Mueller C, Jeger R, Bader F, Osswald S, Kaiser C, BASKET-
LATE investigators: Late clinical events after clopidogrel discontinuation may limit the benefit of drug-eluting stents: an observational study of drug-eluting versus bare-metal stents. J Am Coll Cardiol 2006, 48:2584-9l.

14. Camenzind E, Steg PG, Wijns W: Safety of drug-eluting stents: a metaanalysis of Ist generation DES programs. World Congressof Cardiology 2006, September 2-6, 2006, Barcelona, Spain [http:www.escardio.org/knowledge/congresses/CongressReports/ hotline sandctus/707009 Camenzind.htm].

15. Marzocchi A, Saia F, Piovaccari G, Manari A, Aurier E, Benassi A, Cremonesi A, Percoco G, Varani E, Magnavacchi P, Guastaroba P, Grilli $R$, Maresta $A$ : Long-term safety and efficacy of drug-eluting stents two-year results of the REAL (Registro angioplastiche dell'Emilia Romagna) multicenter registry. Circulation 2007, II 5:3|8I-3188

16. Vanhoutte PM: Endothelial dysfunction and atherosclerosis. Eur Heart J 1997: 19-29.

17. Corti R, Badimon J]: Value or desirability of hemorheologicalhemostatic parameter changes as endpoints in blood lipidregulating trials. Curr Opin Lipidol 200I, I 2:629-37.

18. Luscher TF, Steffel J, Eberli FR, Joner M, Nakazawa G, Tanner FC, Virmani R: Drug-eluting stent and coronary thrombosis: biological mechanisms and clinical implications. Circulation 2007, I | 5: 105I-1058.

19. Park DW, Park SW, Park KH, Lee BK, Kim YH, Lee CW, Hong MK, Kim J], Park SJ: Frequency of and risk factors for stent thrombosis after drug-eluting stent implantation during long-term follow-up. Am J Cardiol 2006, 98:352-356.

20. McFadden EP, Stabile E, Regar E, Cheneau E, Ong AT, Kinnaird T, Sud dath WO, Weissman NJ, Torguson R, Kent KM, Pichard AD, Satler LF, Waksman R, Serruys PW: Late thrombosis in drug-eluting coronary stents after discontinuation of antiplatelet therapy. Lancet 2004, 364:1519-1521.

21. Eisenstein EL, Anstrom KJ, Kong DF, Shaw LK, Tuttle RH, Mark DB, Kramer JM, Harrington RA, Matchar DB, Kandzari DE, Peterson ED, Schulman KA, Califf RM: Clopidogrel use and long-term clinical outcomes after drug-eluting stent implantation. JAMA 2006, 297:159-168.

22. Wenaweser P, Dorffler-Melly J, Imboden K, Windecker S, Togni M, Meier B, Haeberli A, Hess OM: Stent thrombosis is associated with an impaired response to antiplatelet therapy. J Am Coll Cardiol 2005, 45: $1748-1752$.

23. Mehta SR, Yusuf S, Peters RJ, Bertrand ME, Lewis BS, Natarajan MK, Malmberg K, Rupprecht H, Zhao F, Chrolavicius S, Copland I, Fox KA, Clopidogrel in unstable angina to prevent recurrent events trial (CURE) Investigators: Effects of pretreatment with clopidogrel and aspirin followed by long-term therapy in patients undergoing percutaneous coronary intervention: the PCI-CURE study. Lancet $200 \mathrm{I}, 358: 527-533$.

Publish with Bio Med Central and every scientist can read your work free of charge

"BioMed Central will be the most significant development for disseminating the results of biomedical research in our lifetime. "

Sir Paul Nurse, Cancer Research UK

Your research papers will be:

- available free of charge to the entire biomedical community

- peer reviewed and published immediately upon acceptance

- cited in PubMed and archived on PubMed Central

- yours - you keep the copyright 